\title{
Detection of virulence genes in Salmonella serovars isolated from broilers
}

\author{
Ezzat M. E. ${ }^{1}$, Shabana I. I. ${ }^{1}$, Esawy A. M. ${ }^{2}$, Elsotohy M. E. ${ }^{2}$ \\ ${ }^{1}$ Faculty of Veterinary medicine, Department of Bacteriology, Immunology and mycology, Suez Canal University, Ismailia, Egypt \\ ${ }^{2}$ Animal Health Research Institute, Mansoura, Dakahlia
}

Email address:

mezzat05@yahoo.com (Ezzat M. E.),imanibrahim50@yahoo.com (Shabana I. I.)

\section{To cite this article:}

Ezzat M. E., Shabana I. I., Esawy A. M., Elsotohy M. E.. Detection of Virulence Genes in Salmonella Serovars Isolated from Broilers. Animal and Veterinary Sciences. Vol. 2, No. 6, 2014, pp. 189-193. doi: 10.11648/j.avs.20140206.16

\begin{abstract}
This study was conducted to determine the prevalence of Salmonellae in broilers farms in Dakahlia Governorate, Egypt. A total of 1000 samples were collected from 200 broiler chickens (40 apparently healthy, 80 diseased chickens and 80 freshly dead broiler chickens).The samples were liver, caecum, heart blood, spleen \& kidney. The colonial morphology, microscopical and biochemical identifications of the isolates revealed the presence of 37 out of 200 chickens (18.5\%) salmonella species isolates, representing: 3 from apparently healthy chicken (7.5\%), 21 from diseased chickens (26.25\%) and 13 from freshly dead broiler chickens (16.25\%). The rate of recovery of Salmonellae from the different internal organs showed that high recovery rate was from liver, caecum, spleen, heart then kidney as the follow (9.5\%), (5.5\%), (4.5\%), (3\%) and (2\%), respectively. The serotyping of the isolated salmonellae from chickens were eight $S$. enteritidis, one $S$. maccles Field, two $S$. wingrove, one $S$. eingedi, three $S$. rissen, two $S$. derby, two $S$. vejle, one $S$. magherafelt, two $S$. berta, two $S$. enterica sub.spp salamae, one $S$. gueuletapee, one $S$. blegdam, five $S$. kentucky, two $S$. newport, two $S$. agona and two $S$. virchow were isolated from broilers. PCR assay was carried out for six serovars (S. enteritidis, S. maccles Field, S. rissen, S. derby, S. magherafelt and S. enterica sub.spp salamae) to detect the presence of invA, sopB and stn gene, All serovars had the three genes. Gentamycin, ciprofloxacin, colistin sulphate and enrofloxacin were found to be the most effective antimicrobials against the tested isolates; while a high resistance to erythromycin and flumequine were shown. High prevalence of Salmonella in broilers and multidrug resistance, constituting a major concern for public health. Further surveillance programs and research are a necessity to understand their epidemiology and to limit the spread of multidrug-resistant Salmonella spp.
\end{abstract}

Keywords: Salmonella, Broiler, Serotypes, Virulence Genes

\section{Introduction}

Salmonella infection is one of the most serious problems that affect poultry industry causing high economical losses not only due to high mortality in young chickens but also for the debilitating effect which predisposes for many other diseases. Salmonellosis is an important health problem and a major challenge worldwide. Salmonella spp. are recognized as the most causative agents of food poisoning. These organisms are Gram negative and rod shape which have been divided into over 2700 serotypes based on somatic, flagellar and capsular antigens [1] . Salmonellae are short bacilli, 0.7$1.5 \times 2.5 \mu \mathrm{m}$, Gram-negative, aerobic or facultative anaerobic, positive catalase, negative oxidase; they ferment sugars with gas production, produce $\mathrm{H} 2 \mathrm{~S}$, are non sporogenic, and are normally motile with peritricheal flagella, except for
Salmonella Pullorum and Salmonella Gallinarum, which are nonmotile [2]

The genus Salmonella is divided into two species Salmonella enterica and Salmonella bongori; Salmonella enterica itself is comprised of 6 subspecies. They are $S$. enterica subsp. enterica, S. enterica subsp. arizonae, $S$. enterica subsp. diarizonae, $S$. enterica subsp. indica, $S$. enterica subsp. houtenae or I, II, IIIa, IIIb, IV and VI, respectively [3].

Salmonella enterica serovar typhimurium and S. enterica serovar enteritidis are the most frequent isolated serovars worldwide [4]. In Egypt $S$. enteritidis were isolated from broiler chicken, chicken meat and food poisoning patient. The clinical illness characterized by fever, nausea and diarrhea, vomition and abdominal pain after an incubation period of 12 to $72 \mathrm{hrs}$ [5]. 
Many of the virulence genes of $S$. enterica are chromosomal genes located on pathogenicity islands referred to as Salmonella Pathogenicity Islands (SPI). These genes are believed to have been acquired by Salmonella from other bacterial species through horizontal gene transfer. They responsible for host cell invasion and intracellular pathogenesis. Other virulence factors of Salmonella include production of endotoxins and exotoxins, and presence of fimbrie and flagella [6]

This study was planned to identify biochemically and serologically the prevalent Salmonella species in broilers farms in Dakahlia Governorate, Egypt, to detect common virulence genes of Salmonella serovars using Polymerase Chain Reaction, and to detect its susceptibility to various antibiotics.

\section{Material and Methods}

\subsection{Sample Collection}

A total of 200 samples from broilers farms were collected for Salmonella isolation and these samples include liver, caecum, spleen, heart and kidney. All samples were put in sterile plastic bags in ice box and transported directly to Mansoura laboratory (Animal Health Research Institute).

\subsection{Isolation of Salmonella}

According to ISO 6579 (2002) method [7]: Each sample was inoculated separately in selenite $F$ broth and incubated at $37^{\circ} \mathrm{C}$ for not more than 18 hours or Rappaport-Vassiliadis Soya broth (RVS) and incubated at $42^{\circ} \mathrm{C}$ for 24 hours. Then a loopful from selective enriched media was streaked onto plates of MacConkey's, Salmonella-Shigella (S.S) and xylose lysine deoxycholate and incubated overnight at $37{ }^{\circ} \mathrm{C}$. Typical colonies were picked and further tested by standard biochemical methods and serotyped using specific commercial sera.

\subsection{Identification of Salmonella Isolates}

\subsubsection{Microscopic Examination}

Films from suspected purified colonies were prepared, fixed and stained with Gram's.

\subsubsection{Biochemical Identification}

According to ISO 6579 (2002) method: Purified isolates were examined by different biochemical reactions either by oxidase, urea hydrolysis, $\mathrm{H}_{2} \mathrm{~S}$ production on TSI, lysine decarboxylation, indole, methyl red test, Voges-Proskauer, citrate utilization and Analytical profile index 20 E (API 20 E).

\subsubsection{Serological Identification}

Salmonella isolates were serotyped by the slide agglutination method using $\mathrm{O}$ and $\mathrm{H}$ antisera (Difco, Detroit, USA), according to the manufacturer's instructions.

\subsection{Detection of Virulence Genes}

Table (1). PCR primers for amplification of virulence genes

\begin{tabular}{lllc}
\hline Primer & Sequence & PCR product & Reference \\
\hline \multirow{2}{*}{ invA } & $\begin{array}{l}\text { Gtgaaattatcgccacgttcgggcaa } \\
\text { Tcatcgcaccgtcaaaggaacc }\end{array}$ & $284 \mathrm{bp}$ & {$[15]$} \\
\multirow{2}{*}{ sopB } & $\begin{array}{l}\text { Tcagaagcgtctaaccactc } \\
\text { Taccgtcctcatgcacactc }\end{array}$ & $517 \mathrm{bp}$ & {$[8]$} \\
\multirow{2}{*}{ stn } & $\begin{array}{l}\text { Ttg tgt cgc tat cac tgg caacc } \\
\text { Att cgt aac ccg ctc tcg tcc }\end{array}$ & $617 \mathrm{bp}$ & \\
\hline
\end{tabular}

DNA was extracted using QIAamp DNA Mini Kit according to the instructions of the manufacturer. Detection of virulence genes was performed by PCR. Primer sequences and PCR conditions used for the study listed in Table (1). PCR performed in T3 Thermal cycler (Biometra). PCR products were separated and visualized by gel electrophoresis in $1.5 \%$ agarose in Tris-acetate-EDTA (TAE) buffer at $100 \mathrm{~V}$. And Gel Pilot 100 bp ladder (QIAGEN, USA) was included in each agarose run, accordingly the amplified product.

\subsection{Antibiotic Sensitivity Testing}

According to ISO 6579 (2002) method: Determination of the susceptibility of the isolated strains to antibiotic discs was adopted using the disc diffusion technique according to Clinical and Laboratory Standards Institute (CLSI) instructions (CLSI, 2006) [9].

\section{Results}

\subsection{The Prevalence of Salmonella Spp}

Table (2). The prevalence of Salmonella spp. in examined chickens

\begin{tabular}{llll}
\hline Examined chicken & Number of examined chicken & Number of positive \\
\hline Apparently healthy chicken & 40 & 3 & \\
Diseased chicken & 80 & 21 & 7.5 \\
Freshly dead chicken & 80 & 13 & 26.3 \\
Total & 200 & 37 & 16.3 \\
\hline
\end{tabular}

Salmonella suspected isolates showed smooth red colored colonies with black center on XLD, while on Hektone enteric it appeared as deep blue colonies but on MacConkey's agar appeared as pale, colorless smooth, transparent and raised colonies and on Salmonella Shigella (S-S) agar, Salmonella produce colorless colonies with black centers due to $\mathrm{H} 2 \mathrm{~S}$ production. The staining characters appeared as Gram negative, non-spore forming \&short rod shaped. Biochemically, all Salmonella suspected isolates were nonlactose fermenting colonies and negative oxidase, urea hydrolysis, indole and Voges-Proskauer tests. Meanwhile, most isolates produced $\mathrm{H}_{2} \mathrm{~S}$ and positive methyl red, citrate 
utilization and lysine decarboxylation.

The prevalence of Salmonella spp. in examined chickens was depicted in table (2), Salmonella was recovered in 37 samples with an incidence rate $18.5 \%$ (37 out of 200 ).

\subsection{Recovery rate of Salmonella from Internal Organs}

Table (3). recovery rate of Salmonella from internal organs.

\begin{tabular}{lll}
\hline Examined organs & No. of positive & Percentage \\
\hline Liver & 19 & 9.5 \\
Caecum & 11 & 5.5 \\
Spleen & 9 & 4.5 \\
Heart & 6 & 3 \\
Kidney & 4 & 2 \\
Total & 49 & 24.5 \\
\hline
\end{tabular}

The rate of recovery of Salmonella from internal organs was depicted in table (3), the highest recovery rate of Salmonella isolates was found in liver $(9.5 \%)$ followed by caecum $(5.5 \%)$; spleen $(4.5 \%)$; heart $(3 \%)$ and kidney $(2 \%)$.

\subsection{Serotyping}

The results of serotyping of isolated Salmonella species were listed in Table (4). Salmonella isolates (37) were serotyped using "O" and "H" antisera, serotypes recovered were eight $\mathrm{S}$. enteritidis, one $\mathrm{S}$. macclesfield, two $\mathrm{S}$. wingrove, one S. eingedi, three S. rissen,twoS. derby, two S. vejle, one S. magherafelt, two S. berta, two S. enterica sub.spp salamae, one $\mathrm{S}$. gueuletapee, oneS. blegdam, five S. kentucky, two S. newport, two S. agona, two S. virchow were isolated from broilers with percentage of $(21.62 \%),(2.7 \%)$, $(5.4 \%),(2.7 \%),(8.1 \%),(5.4 \%),(5.4 \%),(2.7 \%),(5.4 \%)$, $(5.4 \%),(2.7 \%),(2.7 \%),(13.5 \%),(5.4 \%),(5.4 \%)$ and $(5.4 \%)$ respectively.

Table (4). Serotyping of isolated Salmonella species

\begin{tabular}{|c|c|c|c|}
\hline Serotype & Antigenic formula & No. of positive & $\%$ \\
\hline S. enteritidis & O: $1,9,12 . \mathrm{H} 1 \mathrm{~g}, \mathrm{~m}, \mathrm{H} 2$ - & 8 & 21.62 \\
\hline S. macclesfield & $\mathrm{O}: 9,46 . \mathrm{H} 1 \mathrm{~g}, \mathrm{~m}, \mathrm{~S}, \mathrm{H} 2$ 1,2,7. & 1 & 2.7 \\
\hline S. Wingrove & $\mathrm{O}: 6,8 . \mathrm{H} 1 \mathrm{C}, \mathrm{H} 2 \mathrm{1,2}$ & 2 & 5.4 \\
\hline S. eingedi & $\mathrm{O}: 6,7 . \mathrm{H} 1 \mathrm{~F}, \mathrm{~g}, \mathrm{t}, \mathrm{H} 2 \mathrm{1,2,7}$ & 1 & 2.7 \\
\hline S.rissen & O: $6,7,14$. H1 f,g. H2 - & 3 & 8.1 \\
\hline S. derby & O: $1,4,[5], 12 . H 1 F$, g. H2[1,2] & 2 & 5.4 \\
\hline S.Vejle & $\mathrm{O}: 3,[10],[15] . \mathrm{H} 1 \mathrm{e}, \mathrm{h}, \mathrm{H} 2 \mathrm{1,2}$ & 2 & 5.4 \\
\hline S. magherafelt & $\mathrm{O}: 8,20 . \mathrm{H} 1 \mathrm{I}, \mathrm{H} 2 \mathrm{1}, \mathrm{w}$ & 1 & 2.7 \\
\hline S.berta & $\mathrm{O}: 1,9,12 . \mathrm{H} 1[\mathrm{~F}], \mathrm{g},[\mathrm{t}] \mathrm{H} 2-$ & 2 & 5.4 \\
\hline $\begin{array}{l}\text { S.enterica sub.spp } \\
\text { salamae }\end{array}$ & 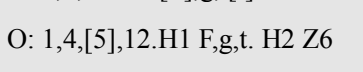 & 2 & 5.4 \\
\hline S. gueuletapee & $\mathrm{O}: 9,12, \mathrm{H} 1 \mathrm{~g}, \mathrm{~m}, \mathrm{~s}, \mathrm{H} 2$ & 1 & 2.7 \\
\hline S.blegdam & $\mathrm{O}: 9,12, \mathrm{H} 1 \mathrm{~g}, \mathrm{~m}, \mathrm{q}, \mathrm{H} 2$ & 1 & 2.7 \\
\hline S. kentucky & $\mathrm{O}: 8,20 . \mathrm{H} 1: \mathrm{i}, \mathrm{H} 2: \mathrm{Z6}$ & 5 & 13.5 \\
\hline S.newport & $\mathrm{O}: 6,8,20 . \mathrm{H} 1: \mathrm{e}, \mathrm{h}, \mathrm{H} 2: 1,2$ & 2 & 5.4 \\
\hline S. agona & $\mathrm{O}: 1,4(5), 12 . \mathrm{H} 1: \mathrm{f}, \mathrm{g}, \mathrm{s}, \mathrm{H} 2:(1,2)$ & 2 & 5.4 \\
\hline S.virchow & $\mathrm{O}: 6,7,14 . \mathrm{H} 1: \mathrm{r}, \mathrm{H} 2: 1,2$ & 2 & 5.4 \\
\hline
\end{tabular}

\subsection{Virulence Genes}

Six salmonella serotypes (S. enteritidis, S. macclesfield, S. rissen, S. derby, S. Magherafelt and S. enterica sub.spp salamae) examined for detection of virulence genes as invA, stn and sopB by conventional PCR.

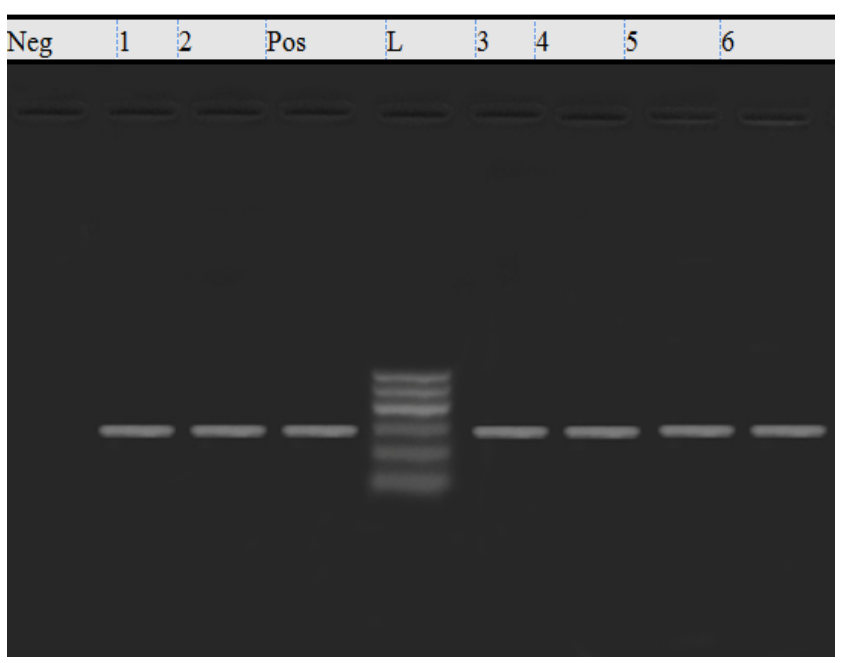

Photo (1). Agarose gel electrophoresis of ampilified invA PCR product (284 bp). Lane L: 100-600pb DNA ladder;Pos.: Positive control; Neg.: Negative control; Lane 1, 2,3,4,5\&6 examined Salmonella.

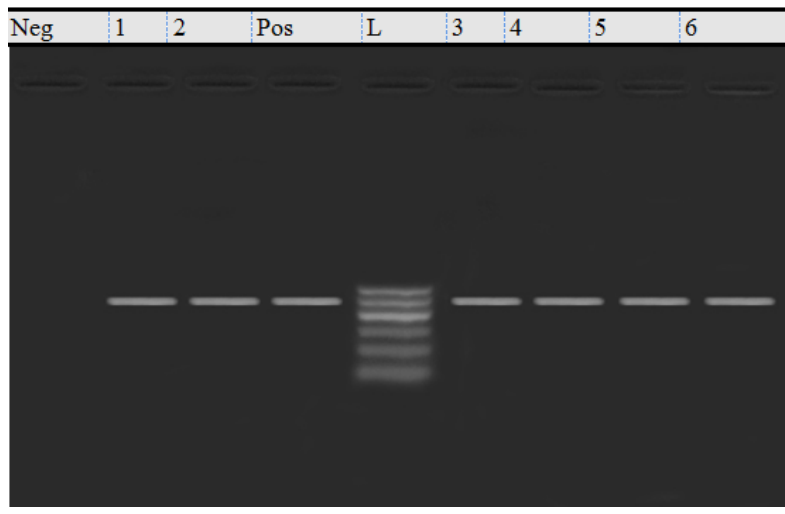

Photo (2). Agarose gel electrophoresis showing Salmonella specific PCR of Salmonella isolates using primer set for the sopB gene(517 bp). Lane L: 100-600pb DNA ladder; Pos.: Positive control; Neg.: Negative control; Lane 12,3,4,5 \&6 examined Salmonella.

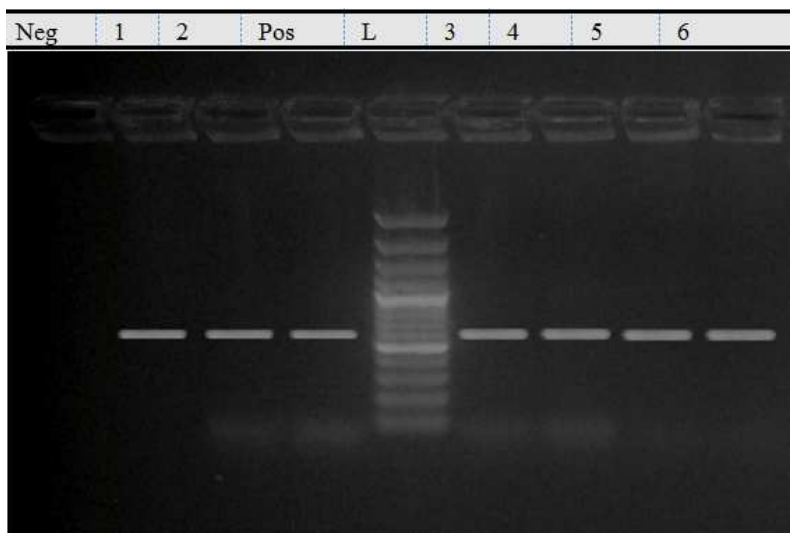

Photo (3). Agarose gel electrophoresis showing Salmonella specific PCR of Salmonella isolates using primer set for the sth (617 bp) gene. Lane L: 1003000pb DNA ladder; Pos.: Positive control; Neg.: Negative control; Lane 1, 2, 3, 4, 5\&6 examined Salmonella.

\section{Discussion}

Salmonella infection is one of the most important bacterial diseases in poultry causing heavy economic loss through 
mortality and reduced production. In the present study, the incidence of Salmonella in broilers was $18.5 \%$ (37out of 200 chickens). This is in agreement with the results obtained by [10]who found that $18 \%$ of broilers were positive for salmonella. However, [11] reported that Salmonella present in $(62.5 \%)$ in examined chickens with higher incidence. The difference in the prevalence rates may be due to socioeconomic factors.

Recovery of Salmonella species from internal organs of the examined chickens were higher from liver followed by caecum, spleen, heart and kidney $9.5 \%, 5.5 \%, 4.5 \%, 3 \%$ and $2 \%$ respectively. It was clear from these results, showed higher isolation rate of Salmonella species from liver. However, [12] isolated Salmonella from tissue samples $22 \%$ $(22 / 100)$.

Serological identification of isolated Salmonella species revealed higher incidence of $S$. enteritidis $(21.62 \%)$ followed by $S$. kentucky(13.5\%), S. rissen $(8.1 \%), 5.4 \%$ for each $S$. wingrove, $S$. derby, S. vejle, S. berta, S. enterica sub.spp salamae, $S$. newport, $S$. agona \& $S$. virchow and $2.7 \%$ for each S. maccles field, S. eingedi, S. magherafelt, $S$. gueuletapeed S.blegdam. These results agree with that reported by [13]. They recorded that the predominant serotypes of Salmonella was S. enteritidis. [14] isolated $S$. Kentucky and Salmonella enteritidis with percentage of $21.64 \%$ and $5.15 \%$, respectively.

[15] revealed that PCR method has high specificity and sensitivity and more importantly a less time consuming procedure than standard microbiological techniques for detection and identification of Salmonella. PCR assay using the invA primers specific for Salmonella spp. considerably decreases the number of false-negative results which commonly occur in diagnostic laboratories. Amplification of invA is now recognized as an international standard procedure for detection of Salmonella genus. In this study, PCR assay was carried out for the detection of the invA gene from six isolated strains $(S$. enteritidis, $S$. macclesfield, $S$. rissen, $S$. derby, S. magherafelt and $S$. enterica sub.spp salamae) has revealed that the gene was present in all of the isolates $(100 \%)$ that was demonstrated by the presence of a 284 bp PCR amplified fragment. The results obtained in the present study were in corroboration with [16]. PCR assay was carried out for the detection of the sopB gene from isolated strains has revealed that the gene was present in all of the isolates $(100 \%)$ which was demonstrated by the presence of a $517 \mathrm{bp}$ PCR product. The results obtained in the present study were in corroboration with [17] and [18]. Also, PCR assay carried out for the detection of the stn gene in Salmonella isolates has revealed that the gene was present in all the isolates $(100 \%)$ that were demonstrated by the presence of a $617 \mathrm{bp}$ PCR product. These findings are in agreement with [19]; [20]and [21]. Observations from the present study indicated that the stn gene is widely distributed among the Salmonella serovars.

In this study all Salmonella strains were sensitive to gentamycin, ciprofloxacin, colistin sulphate and enrofloxacin and this agree with [22] who reported that all the strains were sensitive to at least four antibiotics as gentamicin, chloramphenicol, ceftriaxone and ciprofloxacin. And [23] reported that salmonella isolates were $100 \%$ were resistant to each of erythromycin, penicillin, and amoxicillin, while $98 \cdot 8 \%, 96 \cdot 4 \%, 95 \cdot 2 \%$, and $91 \cdot 6 \%$ were resistant to nalidixic acid, sulphamethoxazole, oxytetracycline, and ampicillin, respectively.

\section{Conclusion}

It could be concluded that there are high level of Salmonella isolation in broilers evaluated in this study may be attributed to horizontal and/or vertical transmission of Salmonella to the chicks. Also, the high rates of antibiotics resistance found in the present study can be explained by the spread of use of antibiotics agents given to poultry in Egypt as prophylaxis, growth promoters or treatment. The multiple resistances observed were to those antimicrobials frequently employed in veterinary practices. We recommend more restrictions on the irrational use of antibiotics and public awareness activities should be undertaken to alert the public to the risks of the unnecessary use of antibiotics. Also, the study recommends that PCR should be used for rapid and sensitive detection of Salmonella.

\section{References}

[1] Gallegos-Robles, M.A., Morales-Loredo, A., Alvarez-Ojeda, G., Vega-P, A., Chew-M, Y., Velarde, S., Fratamico, P.2008. Identification of Salmonella serotypes isolated from cantaloupe and chile pepper production systems in Mexico by PCR-restriction fragment length polymorphism. J Food Prot. 71(11):2217-22.

[2] Plym, F., Wierup, M. 2006. Salmonella contamination: a significant challenge to the global marketing of animal food products. Rev Sci Tech. 25:541-54.

[3] Hendriksen, R.S., Vieira, A.R., Karlsmose, S., Wong, D.M.A., Jensen, A.B. 2011. Global monitoring of Salmonella serovar distribution from the World Health Organization Global Foodborne Infections Network Country Data Bank: results of quality assured laboratories from 2001 to 2007. Foodborne Path Dis 8: 887-900

[4] Chiu, L.H., Chiu, C.H., Horn, Y.M., Chiou, C.S., Lee, C.Y., Yeh, C.M., Yu, C.Y., Wu, C.P., Chang, C.C. and Chu, C. 2010. Characterization of 13 multi-drug resistant Salmonella serovars from different broiler chickens associated with those of human isolates. BMC Microbiol.10:86.

[5] Kovats, R.S., Edwards, S.J., Hajat, S., Armstrong, B.G., Ebi, K.L. and Menne, B. 2004. The effect of temperature on food poisoning: a time-series analysis of salmonellosis in ten European countries. Epidemiol Infect. 132(3):443-53.

[6] Van Asten, A.J. and van Dijk, J.E. 2005. Distribution of classic virulence factors among Salmonella spp. FEMS Immunol. Med. Micribiol.,44, 251-259.

[7] ISO 6579 (2002): Microbiology of food and animal feeding stuffs- horizontal method for the detection of Salmonella SPP. International standard. (Fourth edition) (2002- 07- 15). 
[8] Huehn, S., La Ragione, R.M, Anjum, M., Saunders, M., Woodward, M.J., Bunge, C., Helmuth, R., Hauser, E., Guerra, B., Beutlich, J., Brisabois, A., Peters, T., Svensson, L., Madajczak, G., Litrup, E., Imre, A., Herrera-Leon, S., Mevius, D., Newell, D.G., Malorny, B. 2010. Virulotyping and antimicrobial resistance typing of Salmonella enterica serovars relevant to human health in Europe. Foodborne Pathogens Dis 7:523-35.

[9] Clinical and Laboratory Standards Institute (CLSI): Performance Standards for Antimicrobial Disk Susceptibility Tests, Approved standard-Ninth Edition (M2-A9). Wayne, PA: Clinical and Laboratory Standards Institute; 2006.

[10] Kudaka, J., Itokazy, K., Taira, K., Iwai, A., Kond, M., Sua, T. and Iwanaga, M. 2006. Characterization of Salmonella Isolated in Okinawa, Japan. Jpan. J. Infect .Dis. 59: 15 - 19.

[11] Fofana, A.1. , Bada Alambedji, R., Seydi, M., Akakpo, A.J. 2006. Antibioresistance of Escherichia coli strains isolated from raw chicken meat in Senegal. Dakar Med. 51(1):57-62.

[12] Kumar, T., Rajora, V. R., Arora, N. 2014. Prevalence of Salmonella in pigs and broilers in the Tarai region of Uttarakhand, India. Indian J Med Microbiol.32:99-101.

[13] Ellerbroek, L.1., Narapati, D., Phu, T. N., Poosaran, N., Pinthong, R., Sirimalaisuwan, A., Tshering, P., Fries, R., Zessin, K.H., Baumann, M. and Schroeter, A. 2010. Antibiotic resistance in Salmonella isolates from imported chicken carcasses in Bhutan and from pig carcasses in Vietnam. J Food Prot. 73(2):376-9.

[14] Roy, p., Dhillon, A.S., Lauerman, L.H., Schaberg, D.M., Bandli, D. and Johnson, S. 2002. Results of Salmonella isolation from poultry products, environment and other characteristics. Avian Dis., 13: 793-803.

[15] Oliveira, S.D., Rodenbusch, C.R., Cé, M.C., Rocha, S.L. and
Canal, C.W. 2003. Evaluation of selective and non-selective enrichment PCR procedures for Salmonella detection. Lett Appl Microbiol. 36(4):217-221.

[16] Dione, M.M., Ikumapayi, U., Saha, D., Mohammed, N.I., Adegbola, R.A., Geerts, S., Ieven, M., Antonio, M. 2011. Antimicrobial resistance and virulence genes of non-typhoidal Salmonella isolates in The Gambia and Senegal. J .Infect. Dev. Ctries, 5, 765-775.

[17] Elemfareji, O.I. and Thong, K.L. 2013. Comparative Virulotyping of Salmonella typhi and Salmonella enteritidis. Indian J Microbiol. 53(4):410-7.

[18] Mezal, E.H., Stefanova, R., Khan, A.A. 2013. Isolation and molecular characterization of Salmonella enterica serovar Javiana from food, environmental and clinical samples. Int $\mathrm{J}$ Food Microbiol. 164(1):113-8.

[19] Murugkar, H.V., Rahman, H. and Dutta, P.K. 2003. Distribution of virulence genes in Salmonella serovars isolated from man \& animals. Indian J Med Res.117:66-70.

[20] Prager, R., Fruth, A. and Tschäpe, H. 1995. Salmonella enterotoxin (stn) gene is prevalent among strains of Salmonella enterica but not among Salmonella bongori and other Enterobacteriaceae. FEMS Immunol Med Microbiol; 12 : 47-50.

[21] Rahman, H. 1999. Prevalence of enterotoxin gene (stn) among different serovars of Salmonella. Indian J Med Res; 110: 43-6.

[22] Rajagopal, R. I., Mini, M. and Ramanathan, R. 2013. Outbreaks of salmonellosis in three different poultry farms of Kerala, India, Asian Pac J Trop Biomed; 3(6): 496-500.

[23] Abd-Elghany, S.M., Sallam, K.I., Abd-Elkhalek, A., Tamura, T. 2014. Occurrence, genetic characterization and antimicrobial resistance of Salmonella isolated from chicken meat and giblets. Epidemiol Infect. 8:1-7 